\title{
Ultrasound-mediated microbubble destruction: a new method in cancer immunotherapy
}

This article was published in the following Dove Press journal:

OncoTargets and Therapy

Jiawei Tu

Hui Zhang

Jinsui Yu

Chun Liufu

Zhiyi Chen

Department of Ultrasound Medicine, Laboratory of Ultrasound Molecular Imaging, The Third Affiliated Hospital of Guangzhou Medical University, Guangzhou, 510150, People's Republic of China
Correspondence: Zhiyi Chen

Laboratory of Ultrasound Molecular Imaging, The Third Affiliated Hospital of

Guangzhou Medical University, No. 63

Duobao Road, Liwan District, Guangzhou

510150, People's Republic of China

Tel +860208129 III5

Emailwinchen@vip.I26.com

\begin{abstract}
Immunotherapy provides a new treatment option for cancer. However, it may be therapeutically insufficient if only using the self-immune system alone to attack the tumor without any aiding methods. To overcome this drawback and improve the efficiency of therapy, new treatment methods are emerging. In recent years, ultrasound-mediated microbubble destruction (UMMD) has shown great potential in cancer immunotherapy. Using the combination of ultrasound and targeted microbubbles, molecules such as antigens or genes encoding antigens can be efficiently and specifically delivered into the tumor tissue. This review focuses on the recent progress in the application of UMMD in cancer immunotherapy.
\end{abstract}

Keywords: ultrasound, microbubble, cancer, immunotherapy

\section{Introduction}

The incidence of and mortality due to cancer remain high. Substantial progress has been made using conventional treatments, including surgery, chemotherapy and radiotherapy; however, relapse, metastasis and drug resistance remain the major roadblocks on the path to conquering cancer. ${ }^{1}$ Therefore, effective strategies to eradicate tumors are urgently needed. ${ }^{2}$

Immunotherapy has been increasingly drawing clinicians' and scientists' attention owing to its effectiveness in cancer treatment. ${ }^{3}$ Compared with other strategies for cancer therapy, immunotherapy has the unique advantage of high specificity for the tumor cell while leaving normal cells unharmed. Therefore, the adverse reactions caused by drug therapy can be avoided. Moreover, curative effects of cancer immunotherapy are its rapid onset and long duration, which are different from other strategies.

During immunotherapy, the patient's immune system is activated and enhanced through administration of immune-stimulating substances with long-lasting therapeutic effects. In addition, the anamnestic effects of the host immune system, which account for recurrence prevention, can be induced by immunotherapy. ${ }^{4}$ Immunotherapy, which characteristically has mild adverse effects and sustainable efficacy, holds great promise for cancer treatment. ${ }^{5}$ Cancer vaccines, antibodies, cytokines and adoptive cell therapy (ACT) are widely used in cancer immunotherapy. Immune-activating molecules can be packaged into a recombinant protein or provided in the form of genes during drug administration. ${ }^{6}$ However, the physicochemical properties of these molecules, including their surface charge, hydrophilicity and size, may affect their specificity, eventually weakening their therapeutic effects. ${ }^{7}$

In recent years, with the development of materialogy, which has brought great benefits to the preparation of ultrasound (US) contrast agents, ultrasound-mediated microbubble destruction (UMMD) has become a versatile technology with great 
potential in cancer immunotherapy. UMMD is a targetspecific, non-invasive, effective and novel gene/drug delivery system, in which the microbubbles serve as a gene/drug vehicle or gene/drug delivery enhancer. UMMD leads to acoustic cavitations and induces the generation of physical forces, such as implosions, shock waves, microstreaming and liquid jets, and these forces can induce the disruption of the cytomembrane and enhance the permeability of the cytomembrane. Therefore, drugs, genes, antibodies and cytokines can be directly delivered into the cytoplasm of immune cells, thus enhancing the immune response. ${ }^{8}$ Differently from other technologies, UMMD has been shown to increase the delivery of immune-stimulating substances to tumors without causing any severe damage.

\section{Cancer immunotherapy}

For cancer patients, immunotherapy is a type of cancer therapy in which the antitumor immune response is activated so that it can act to directly attack tumor cells but leave normal cells unharmed. ${ }^{9}$ Cancer immunotherapy can be mediated in different ways: via cancer vaccines; through the application of monoclonal antibodies; via delivery of cytokines, such as interferon (IFN) and interleukins (ILs); and by adoptive cell transfer, including natural killer (NK) cells and T-regulatory cells ( $\mathrm{T}$ cells). ${ }^{10,11}$

In general, cancer immunotherapy can be divided into two types: active cancer immunotherapy and passive cancer immunotherapy. Active immunotherapy means that the immune response is generated by an antigen, such as a cancer vaccine, while passive immunotherapy refers to specific immune substances, such as antibodies or sensitized lymphocytes, that are reinjected into the host body to obtain specific immunity without any antigen. ${ }^{12}$ Both therapeutic strategies can be enhanced by UMMD.

\section{Effects of UMMD}

UMMD is a promising technique for non-invasive, targeted drug and gene delivery, and its applications for immunomodulatory substance delivery to tumor tissues have attracted increasing interest. ${ }^{13}$ The movement and destruction of USmediated microbubbles can trigger enhanced permeability of cytomembranes, open tight junctions (eg, the blood-brain barrier [BBB], blood-tumor barrier and interendothelial junctions) and promote cell endocytosis, thereby providing a transient and invertible channel for the delivery of drugs, genes or gene vehicles and other macromolecules across the endothelial gap and across biological membranes. ${ }^{14-16}$

Under US irradiation, microbubbles explode and oscillation and destruction are induced. ${ }^{17}$ Thus, ruptured microbubbles can serve as a tool to induce local energy release using the acoustic radiation force (ARF), microstreaming, shock waves, microjets and strains. These forces have a direct influence on the cell membrane and vascular wall, enhancing the delivery efficiency of a drug/gene into the cytoplasm. ${ }^{18}$ The common mechanisms of UMMD technology include a cavitation effect, a heat effect, ARF and acoustic droplet vaporization (ADV) (Figure 1). ${ }^{19}$

\section{Cavitation effect}

The cavitation effect is based on the interaction between microbubbles and US. Under a US field at low power, microbubbles oscillate symmetrically and linearly, implying an opposite tendency of the expansion and compression of a microbubble. The situation is different for higher US intensities. In a high-intensity US field, microbubbles behave nonlinearly and expand significantly to a state larger than twice the initial size followed by rupture, causing a high acoustic pressure in a local area, which may be as high as several thousand atmospheres. ${ }^{20}$ These two phenomena are also known as stable cavitation (or non-inertial cavitation) and inertial cavitation. Stable cavitation refers to the oscillation phenomenon in which a microbubble dilates at its syntonous size, creating a liquid flow called microstreams around the microbubbles. When these oscillating microbubbles reach cells, shear stress is generated, enhancing the permeability of the cell membrane. ${ }^{21,22}$

It is commonly recognized that inertial cavitation is a crucial mechanism of cavitation that always occurs under a high acoustic field. Inertial cavitation is characterized by sudden expansions and subsequently rapid collapses of gas microbubbles caused by microbeams. ${ }^{23}$ Microbeams can produce a shear force on the surface of microtubules, causing microbubbles to deform or even rupture. ${ }^{24}$ The energy induced by microbubble destruction can cause various biological effects, such as temporary holes in the cell membrane, which promote entry of drugs and genes into cells, subsequently enhancing the antitumor immune response of the host body (Figure 2).

The cavitation of microbubbles can trigger many cell bioeffects, especially the enhancement of cell endocytosis. ${ }^{25}$ According to a recent study, $\mathrm{Ca}^{2+}$ can immediately excite endocytosis for cytomembrane resealing. ${ }^{26,27}$ Fan et al found that the intracellular $\mathrm{Ca}^{2+}$ concentration was simultaneously increased with the function of cavitation and onset of sonoporation, and gradually recovered to the normal level within approximately 100 seconds. ${ }^{28}$ In this way, during the time window when the $\mathrm{Ca}^{2+}$ level was increased, endocytosis was also enhanced by the cavitation and sonoporation. Moreover, 
A



Enhanced endocytosis

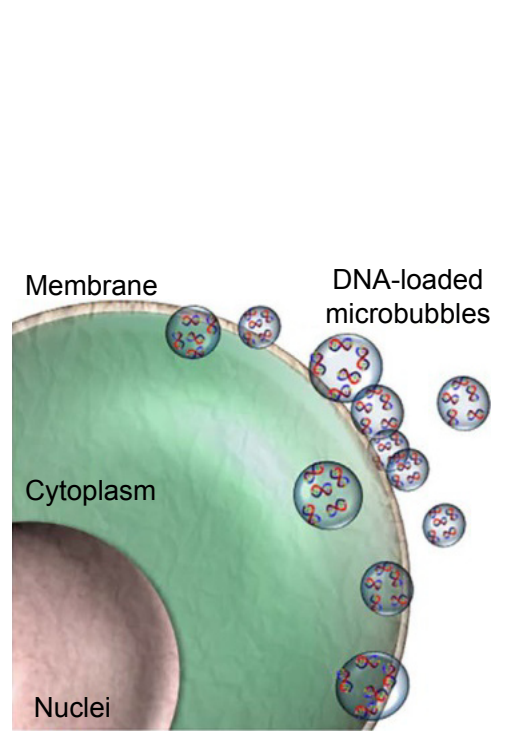

Before sonication

C
B $\quad$ Ultrasound

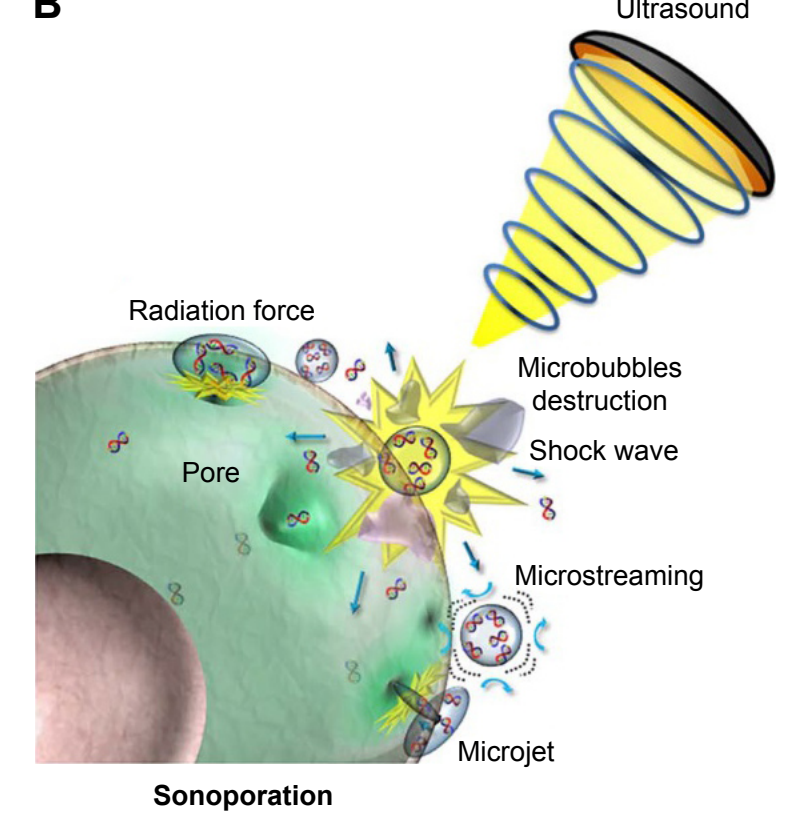

D

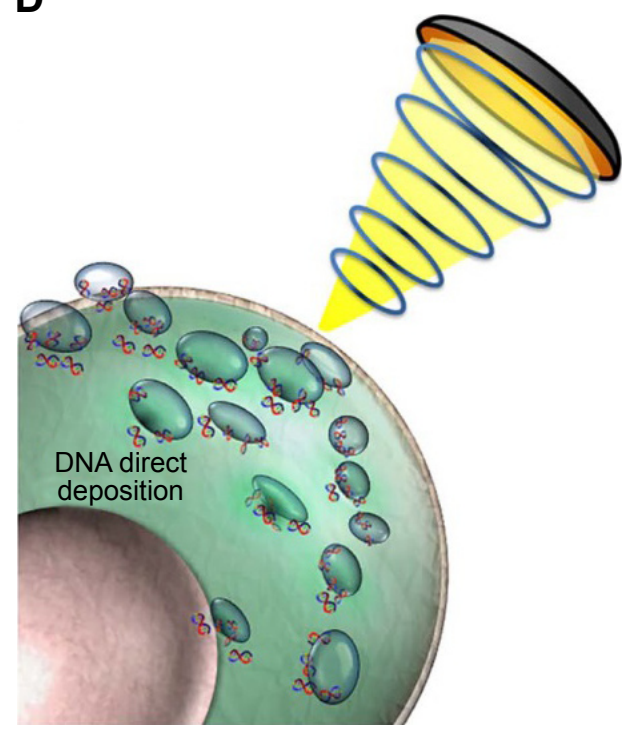

Sonoprinting

Figure I UMMD enhances the microbubble payload delivery into the cell.

Notes: (A) Observation of the cell and microbubble before US sonication. (B) In the field of US, the microbubbles oscillate and rupture, resulting in a series of physical effects including shock waves, microstreaming and microjets. (C) These physical effects increase the permeability of the cytomembrane so that endocytosis is enhanced. (D) The acoustic radiation force pushes the microbubble payload to the exosurface of the cell. Reprinted from Journal of Controlled Release, Volume 26I, Fan $\mathrm{CH}$, Lin $\mathrm{CY}$, Liu $\mathrm{HL}$, Yeh CK, Ultrasound targeted CNS gene delivery for Parkinson's disease treatment, pages 246-262, (C) 2017 with permission from Elsevier. ${ }^{19}$

Abbreviations: UMMD, ultrasound-mediated microbubble destruction; US, ultrasound.

several substances (eg, ceramide) were secreted by lysosomes (delivered to the damaged membrane), which can induce endocytosis and rapid formation of endosomes. ${ }^{29}$

\section{Acoustic radiation force}

Oscillating microbubbles located inside the vascular structure in an acoustic field can translate toward the vascular wall through the ARF. ${ }^{30}$ The microbubbles translate in the direction of wave diffusion in the case of a traveling acoustic wave.
It is not easy to translate freely with the restriction of fluid shear and the floating action in the vasculature. With the help of the pressure gradient induced by ARF, microtubules can move away from the sound source. Hence, microbubbles can be delivered to targeted areas and adhere to the targeted cells. ${ }^{31}$ According to Rychak et al, ARF can promote a shift and aggregation of microbubbles toward the vascular wall, increasing the adhesion rate of targeted microbubbles 60-80-fold. ${ }^{32}$ 


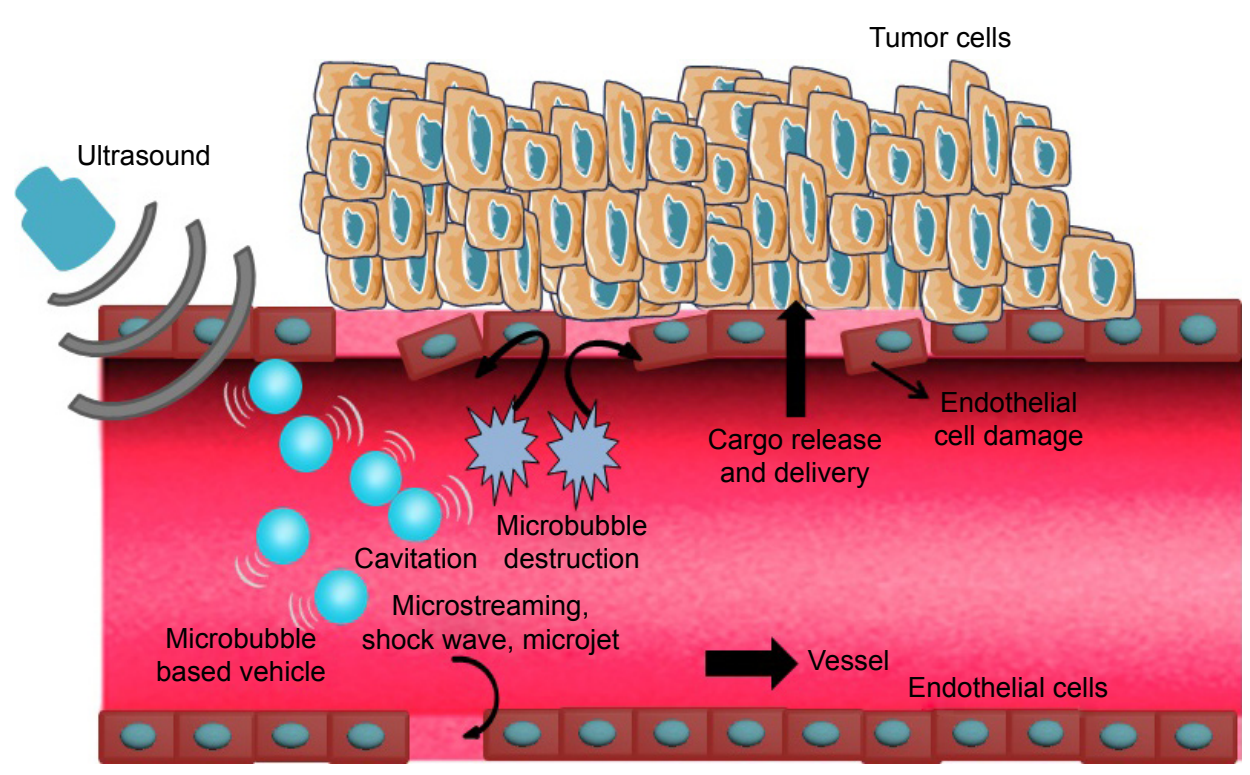

Figure 2 Schematic of enhanced delivery of UMMD.

Notes: The microbubble-based vehicles (ie, gene/drug-loaded microbubbles) oscillate and even rupture under the US irradiation. Therefore, a series of physical forces is generated (including microstreaming, shock waves and microjets), which cause damage to endothelial cells. The released cargo can be delivered into tumor tissue more effectively.

Abbreviations: UMMD, ultrasound-mediated microbubble destruction; US, ultrasound.

UMMD and ARF have a synergistic effect, which can cause tissue damage and reduces the side effects of intravenous administration while improving microbubble targeting to tissues. ARF impacts the fluidity of lipid bimolecular membranes, resulting in a shear force, broadening the space of endothelial cells, increasing the permeability of capillaries and promoting gene or drug delivery. ${ }^{33}$

\section{Acoustic droplet vaporization}

In general, the continuous microvascular structure and dense normal endothelial gap make it difficult for macromolecules to penetrate the blood vessel wall. By contrast, the leaky blood vessels surrounding tumor tissues show heterogeneous hyperpermeability, which leads to penetration and retention of macromolecule material in the tumor bed, which is known as the enhanced permeation and retention (EPR) effect. During cancer therapy, high delivery of macromolecular drugs and genes based on the EPR effect is strongly dependent on the permeability of the tumor microvasculature. ${ }^{34-36}$

Owing to the inherent leakiness of the underdeveloped tumor vasculature, the enhanced permeability enables nanoparticles loaded with drugs or genes to escape the circulation and assemble at tumor tissues. ${ }^{37}$ Therefore, nanodroplets that rely on the EPR effect to target tumors prolong the halflife of drugs and enhance their efficacy, with reduced side effects. EPR-based nanodroplets are widely used in medicine. For example, albumin-bound paclitaxel nanodroplets were approved by the US Food and Drug Administration to treat breast cancer in $2005 .{ }^{38}$ Furthermore, paclitaxel-loaded nanodroplets were recently used in a clinical trial to treat non-small-cell lung cancer. ${ }^{39}$ The liquefied gas nanodroplets are much are much smaller than microbubbles and can load much more gas. In an acoustic field of sufficient intensity, these nanodroplets are transformed into gas bubbles that are triggered by acoustic waves without obviously causing heating effects on surrounding normal tissues. ${ }^{40}$ Such a phase-change phenomenon is called ADV, which was first described in the 1990s and has subsequently been widely used in imaging for preclinical trials. ${ }^{41}$ Recently, the application of ADV in drug delivery has received extensive attention. ${ }^{42}$ Since the diameter of these liquid droplets is sufficiently small to traverse the lungs, they can easily pass through the narrow space of tumor tissues. ${ }^{43}$ Furthermore, transudatory nanodroplets vaporized into gas bubbles can be activated by acoustics, leading to cavitation in the membranes of tumor tissues to enhance drug delivery. ${ }^{44}$ Thus, efficient delivery of the nanodroplets loaded with mRNA encoding a tumor antigen can induce a significant immunostimulatory effect that is meaningful for antitumor immunotherapy.

\section{Immunotherapy assisted by UMMD}

Low-frequency US combined with microbubbles simultaneously promotes dendritic cells (DCs) to differentiate and mature in the cancer microenvironment. ${ }^{45}$ In addition, this 
phenomenon promotes T lymphocytes to trigger antitumor immunity mediated by $\mathrm{T}$ lymphocytes, which enhance the efficacy of angiogenesis targeting. ${ }^{46}$ UMMD has been widely applied as a tool to enhance the delivery of immunomodulatory materials, such as cancer vaccines, antibodies, adoptive cells and cytokines, resulting in enhancement of the immunotherapy effect. Relevant reports of UMMD-triggered immune effects are listed in Table 1.

\section{Cancer vaccination}

Cancer vaccination is attracting increasing attention as a promising therapy strategy for the prevention and treatment of tumor growth, as well as metastasis. Immunotherapy by cancer vaccination has gradually become the mainstream strategy in recent years. Cancer vaccines can be divided into the following types: tumor antigen vaccine (polypeptide vaccine and DNA vaccine), whole-cell vaccine (tumor cell vaccine and dendritic cell [DC]-based vaccine), bacterial vector vaccine, and so on. ${ }^{47}$ Among these, DC-based vaccine and DNA vaccine are mostly commonly used in cancer immunotherapy. However, effective treatment by cancer vaccination needs a high delivery efficiency of cancer antigen into host antigen-presenting cells (APCs) to activate the immune response. Consequently, cancer vaccination is a targeted therapy with quite low adverse effects.

\section{DC-based vaccination}

DCs have unique capabilities involving innate and adaptive immune responses, making them an ideal APC to boost antitumor attack. ${ }^{47,48}$ In numerous clinical trials, DC-based vaccines have been shown to be safe and effective in cancer immunotherapy. ${ }^{49}$ During DC-based vaccine therapy, loading DCs with tumor antigens and subsequently activating DCs are crucial. It has been demonstrated that transfection is significantly enhanced using microtubules, and US can activate powerful immune responses in vivo, which can be applied as a potential method for further clinical trials (Figure 3). ${ }^{50}$ Oda et al used microbubbles combined with US

Table I Summary of experiments and immune responses after treatment with UMMD

\begin{tabular}{|c|c|c|c|c|c|c|c|}
\hline $\begin{array}{l}\text { Experiment } \\
\text { type }\end{array}$ & $\begin{array}{l}\text { Animal typel } \\
\text { cell type }\end{array}$ & Tumor type & $\begin{array}{l}\text { US-sensitive } \\
\text { vehicle }\end{array}$ & $\begin{array}{l}\text { Immunostimulation } \\
\text { materials }\end{array}$ & US parameter & $\begin{array}{l}\text { Immune } \\
\text { effect }\end{array}$ & Reference \\
\hline In vivo & C57BL/6 mice & Melanoma & Microbubbles & Antigen and mRNA & $\begin{array}{l}\text { I } \mathrm{MHz}, 2 \mathrm{~W} / \mathrm{cm}^{2} \text {, } \\
20 \% \text { duty, } 30 \text { seconds } \\
\text { insonation time }\end{array}$ & $\begin{array}{l}\text { Tumor } \\
\text { outgrowth } \downarrow\end{array}$ & $\begin{array}{l}\text { Dewitte } \\
\text { et } \mathrm{al}^{50}\end{array}$ \\
\hline In vivo & C57BL/6 mice & Melanoma & $\begin{array}{l}\text { Liposome } \\
\text { microbubbles }\end{array}$ & Antigens & $\begin{array}{l}2 \mathrm{MHz}, 2.0 \mathrm{~W} / \mathrm{cm}^{2}, 10 \% \\
\text { duty, } 3 \times 10 \text { seconds } \\
\text { insonation time }\end{array}$ & $\begin{array}{l}\text { Melanoma lung } \\
\text { metastases } \downarrow\end{array}$ & Oda et $\mathrm{al}^{51}$ \\
\hline In vivo & C57BL/6 mice & $\begin{array}{l}\text { Ovarian } \\
\text { carcinoma }\end{array}$ & $\begin{array}{l}\text { PEG-modified } \\
\text { bubble lipoplexes }\end{array}$ & pDNA & Not mentioned & $\begin{array}{l}\text { Antitumor } \\
\text { effects } \uparrow\end{array}$ & Un et $\mathrm{al}^{57}$ \\
\hline In vivo & C57BL/6 mice & Melanoma & $\begin{array}{l}\text { Mannose-modified } \\
\text { bubble lipoplexes }\end{array}$ & pDNA & $\begin{array}{l}\mathrm{I} .045 \mathrm{MHz}, \mathrm{I} .0 \mathrm{~W} / \mathrm{cm}^{2} \text {, } \\
50 \% \text { duty, I minute } \\
\text { insonation time }\end{array}$ & $\begin{array}{l}\text { Transcriptional } \\
\text { factors } \uparrow\end{array}$ & $\begin{array}{l}\text { Yoshida } \\
\text { et } \mathrm{al}^{59}\end{array}$ \\
\hline In vitro & $\begin{array}{l}\text { DLDI and } \\
\text { AGS cells }\end{array}$ & $\begin{array}{l}\text { Colorectal } \\
\text { cancer }\end{array}$ & $\begin{array}{l}\text { Phase-change } \\
\text { nanodroplets }\end{array}$ & Antibody & $\begin{array}{l}\mathrm{I} 00 \text { cycles at } 4 \mathrm{MHz} \\
\mathrm{I} .5 \mathrm{MPa} \text { peak negative } \\
\text { pressure }\end{array}$ & $\begin{array}{l}\text { Tumor cell } \\
\text { apoptosis } \uparrow\end{array}$ & $\begin{array}{l}\text { Ishijima } \\
\text { et } \text { al }^{64}\end{array}$ \\
\hline In vivo & Nude rats & $\begin{array}{l}\text { Brain } \\
\text { metastasis }\end{array}$ & Microbubbles & Antibody & $\begin{array}{l}0.40-0.70 \mathrm{~W} / \mathrm{cm}^{2}, \\
10 \mathrm{~ms} \text { burst sonications, } \\
0.46-0.62 \mathrm{MPa} \text { peak } \\
\text { negative pressure }\end{array}$ & $\begin{array}{l}\text { Tumor } \\
\text { outgrowth } \downarrow\end{array}$ & $\begin{array}{l}\text { Kobus } \\
\text { et } \mathrm{al}^{71}\end{array}$ \\
\hline In vivo & $\begin{array}{l}\text { Athymic nude } \\
\text { rats }\end{array}$ & $\begin{array}{l}\text { Breast cancers } \\
\text { with HER2 }\end{array}$ & $\begin{array}{l}\text { Definity } \\
\text { microbubble }\end{array}$ & NK-92 & $\begin{array}{l}55 \mathrm{I} .5 \mathrm{kHz} \text { focused } \\
\text { transducer, } 0.33 \\
\mathrm{MPa} \text { average peak } \\
\text { rarefaction pressure }\end{array}$ & $\begin{array}{l}\text { NK-92 brain } \\
\text { delivery } \uparrow\end{array}$ & $\begin{array}{l}\text { Alkins } \\
\text { et } \mathrm{al}^{82}\end{array}$ \\
\hline In vitro & $\begin{array}{l}\text { Tregs from } \\
\text { HCC patients }\end{array}$ & $\begin{array}{l}\text { Hepatocellular } \\
\text { carcinoma }\end{array}$ & $\begin{array}{l}\text { SonoVue } \\
\text { microbubble }\end{array}$ & T cells & $\begin{array}{l}10 \% \text { microbubbles, } \\
1.4 \text { mechanical index, } \\
150 \text { or } 180 \text { seconds } \\
\text { insonation time }\end{array}$ & $\begin{array}{l}\text { Treg } \\
\text { proliferation } \uparrow\end{array}$ & Shi et $\mathrm{al}^{88}$ \\
\hline In vivo & $\begin{array}{l}\text { C57BL/6 X } \\
\text { C3H/He mice }\end{array}$ & $\begin{array}{l}\text { Ovarian } \\
\text { carcinoma }\end{array}$ & Bubble liposomes & pDNA & $\begin{array}{l}\text { I } \mathrm{MHz}, 0.7 \mathrm{~W} / \mathrm{cm}^{2}, \\
60 \text { seconds insonation } \\
\text { time }\end{array}$ & $\begin{array}{l}\text { Tumor } \\
\text { outgrowth } \downarrow\end{array}$ & $\begin{array}{l}\text { Suzuki } \\
\text { et } \text { al }^{94}\end{array}$ \\
\hline
\end{tabular}

Notes: $\uparrow$, up regulated; $\downarrow$, down-regulated.

Abbreviations: HCC, hepatocellular carcinoma; NK, natural killer; PEG, poly(ethylene glycol); Treg, regulatory T cell; UMMD, ultrasound-mediated microbubble destruction; US, ultrasound. 


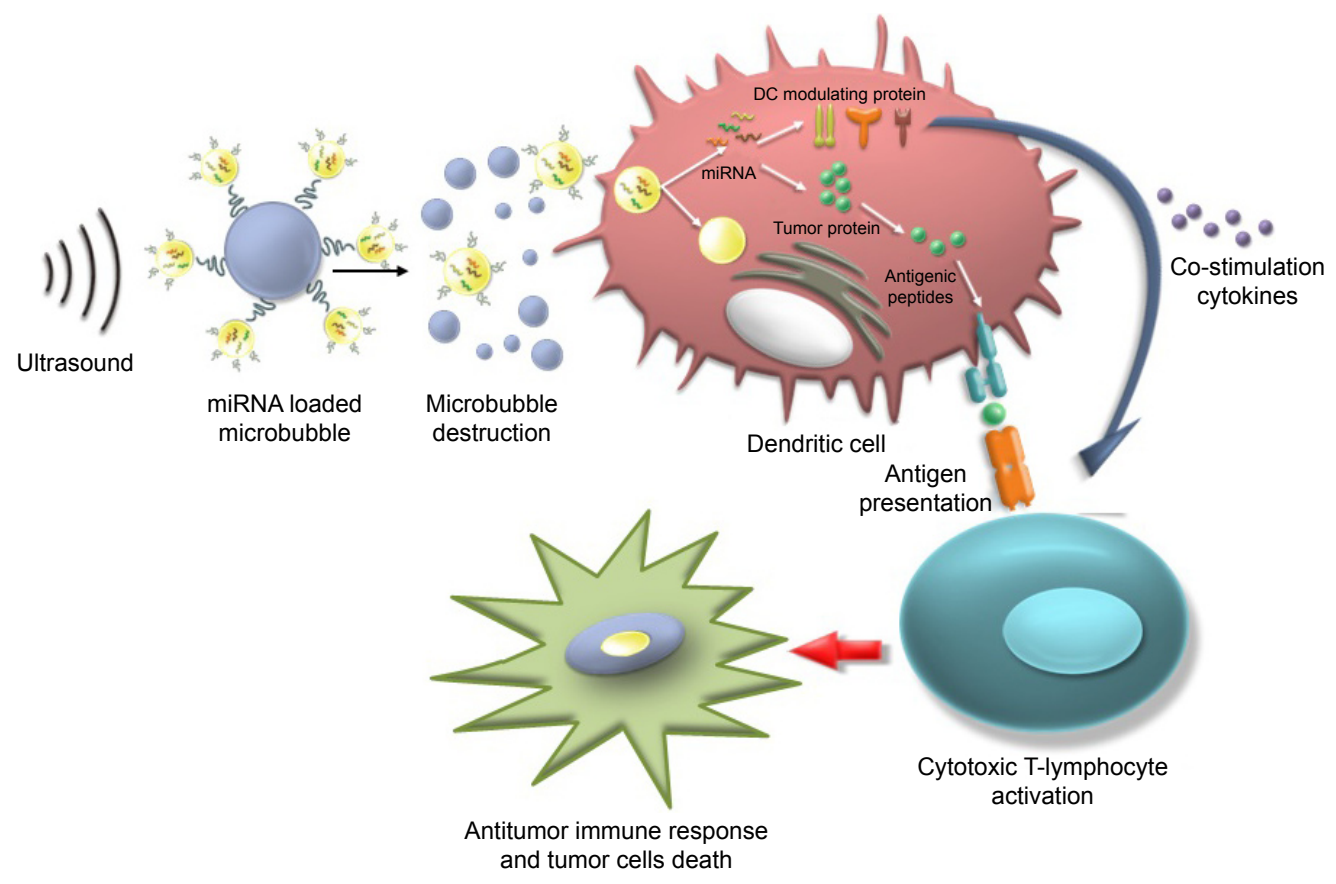

Figure 3 Schematic of the use of US with mRNA-loaded microbubbles.

Notes: The mRNA-loaded microbubbles implode upon exposure to US and sonoporate the DCs. As a result, both antigen- and DC-modulating proteins are produced by the DC, which can lead to antigen presentation and T-cell activation. Reprinted from the Journal of Controlled Release, Volume 194(I2), Dewitte H, Van Lint S, Heirman C, et al, The potential of antigen and TriMix sonoporation using mRNA-loaded microbubbles for ultrasound-triggered cancer immunotherapy, pages 28-36, Copyright @ 20I4, with permission from Elsevier. ${ }^{50}$

Abbreviations: DC, dendritic cell; US, ultrasound.

irradiation to deliver antigens that were extracted from tumor cells into DCs and then investigated the therapeutic effect of the treated DCs on a mouse model of lung metastasis. The results demonstrated that prophylactic immunization with this strategy showed significant suppression (a four-fold decrease) of melanoma lung metastases. ${ }^{51}$

\section{DNA vaccination}

Several studies have reported that DNA vaccination can activate the immune response, including humoral immunity and cellular immunity, using cancer antigens encoded by exogenous tumor-associated genes. ${ }^{48,52}$ An exogenous gene encoding cancer antigens is called a DNA vaccine. ${ }^{53,54}$ To achieve the full therapeutic effects of DNA vaccination, it is necessary to divert the antigen-coding gene selectively and effectively into APCs (macrophages and DCs), which play a critical role in the initiation, programming and regulation of antitumor immune responses. ${ }^{55}$

Many researchers have demonstrated that the effects of cancer vaccination can be improved by UMMD-triggered gene transfection technologies. ${ }^{56} \mathrm{Un}$ et al developed a mannosemodified gene carrier called Man- $\mathrm{PEG}_{2000}$ [mannosepoly(ethylene glycol) 2000] bubble lipoplexes to deliver a DNA vaccine into APCs, resulting in high antitumor effects (Figure 4). ${ }^{57}$ With the help of these transfection methods, it is possible to deliver a large amount of gene-loaded antigen as well as antigen peptides into APCs. ${ }^{58}$ Yoshida et al synthesized a USresponsive gene carrier (doxorubicin-encapsulated poly(ethylene glycol)-modified liposome microbubble) to deliver the DNA vaccine. The results suggested that the combination of US and the DNA vaccination-loaded liposome microbubble can increase the delivery of DNA vaccine, inducing an effective therapeutic outcome for cancer immunotherapy. ${ }^{59}$

\section{Antibody-based immunotherapy}

Because immunoregulation of antitumor treatments is often used clinically today, therapeutic antibodies that can distinguish tumor cells have been developed in recent years. Antibodies can provide effective treatment by targeting specific molecular targets, thus inhibiting tumor cell growth. ${ }^{60}$

Bevacizumab is a drug that targets vascular endothelial growth factor (VEGF) and tumor neovascularization, subsequently inhibiting the biological function of VEGF ${ }^{61}$ Liu et al reported enhanced delivery of the antiangiogenic antibody bevacizumab into the central nervous system using the combination of focus US, microbubble and magnetic resonance imaging (MRI) monitoring. ${ }^{62}$ Rituximab is another antibody that can specifically bind to $\mathrm{CD} 20^{+}$lymphoma cells and induce cell apoptosis. ${ }^{63}$ In 2017, Ishijima et al developed a phase-change nanodroplet conjugated with an antitumor 


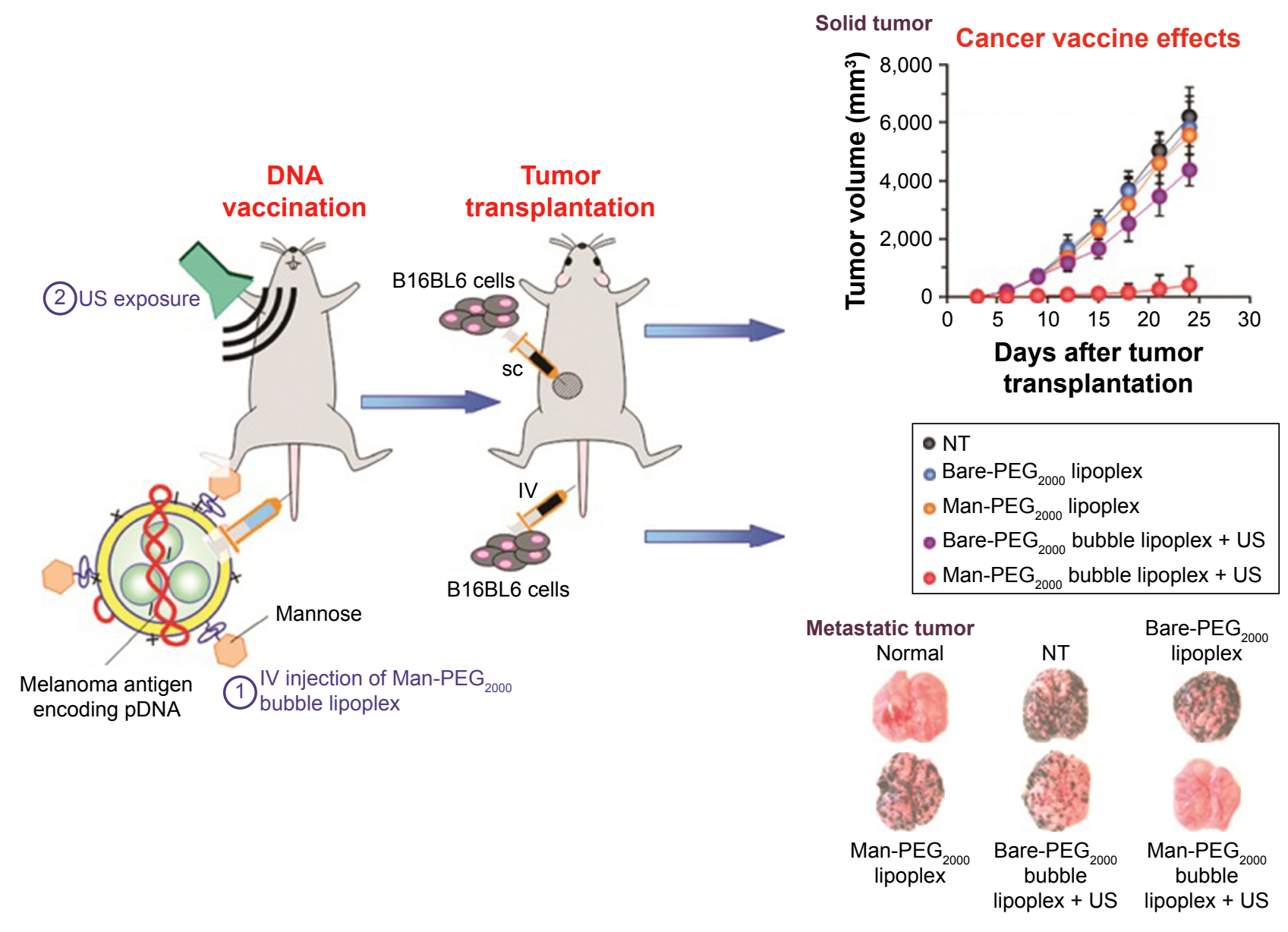

Figure 4 Schematic representation of the treatment method of US exposure combined with pDNA-loaded microbubbles.

Notes: During this treatment, the pDNA-loaded bubbles are ruptured by the US irradiation and release the loading melanoma antigen-encoding pDNA in vivo. In this way, the treated mouse obtains antimelanoma immunity. Reproduced with permission from Un K, Kawakami S, Suzuki R, Maruyama K, Yamashita F, Hashida M. Suppression of melanoma growth and metastasis by DNA vaccination using an ultrasound-responsive and mannose-modified gene carrier. Mol Pharm. 20II;8(2):543-554. Copyright (C) 20II, American Chemical Society. ${ }^{57}$

Abbreviations: Man, mannose; PEG $_{2000}$, poly(ethylene glycol) 2000; NT, not treatment; SC, subcutaneous; US, ultrasound.

antibody (9E5), and in vitro experiments showed that the antibody was delivered to $97.8 \%$ of high-epiregulin-expressing cancer cells and that $57 \%$ of those cancer cells were killed with US irradiation (Figure 5) ${ }^{64}$

However, antibody-based immunotherapy is less efficient in solid tumors because it is difficult to enrich antibodies within the tumor and the bioavailability in the tumor is very poor. ${ }^{65}$ Thus, systemic and repeated delivery of a high antibody dose is essential to reach the therapeutic concentration, which increases the side effects and costs. ${ }^{66}$ Monoclonal antibodies targeting the HER2 protein, such as trastuzumab, have the potential to prolong the survival of patients with HER $2^{+} .{ }^{67}$ Trastuzumab is a humanized monoclonal antibody that is widely used in clinical treatment. However, several recent studies have reported that the use of a large amount of trastuzumab resulted in an increasing incidence of brain metastases. ${ }^{68}$

Antibodies and other drugs are often unsatisfactory for the treatment of brain metastases because the BBB and blood-tumor barrier prevent most drugs entering the brain. ${ }^{69}$ To effectively treat brain metastases and reduce side effects, drugs or genes must be delivered efficiently to the brain. ${ }^{70} \mathrm{In}$ the study by Kobus et al, HER2-targeting antibodies combined with US and Optison (GE Healthcare, Milwaukee, WI, USA) ${ }^{\mathrm{TM}}$ were utilized to inhibit the growth rate of a tumor model derived from HER2-positive breast cancer metastasis to the brain. The results demonstrated that the antitumor effects of antibodies can be significantly enhanced by the synergism of US and Optison. ${ }^{71}$

\section{Adoptive cell therapy}

As a highly individualized cancer therapy, ACT involves the regulation of the tumor-bearing host's immune cells with direct antitumor activity. ${ }^{72,73} \mathrm{ACT}$ has been shown to be more effective than other cancer immunotherapies, although it relies on abundant antitumor immune cells with high activity, including regulatory $\mathrm{T}$ cells (Tregs) and NK cells. ${ }^{74}$ 
A

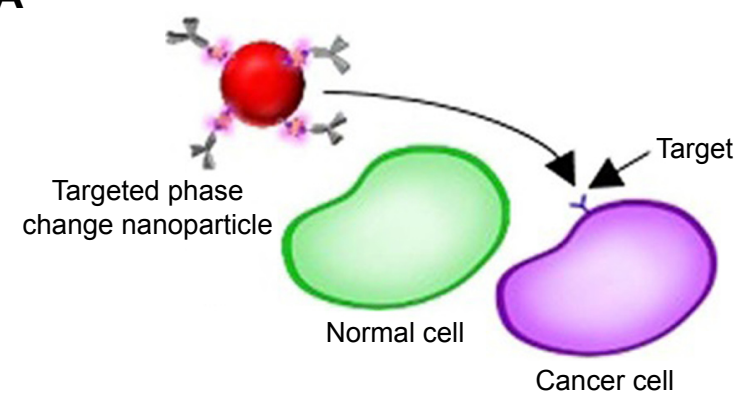

B

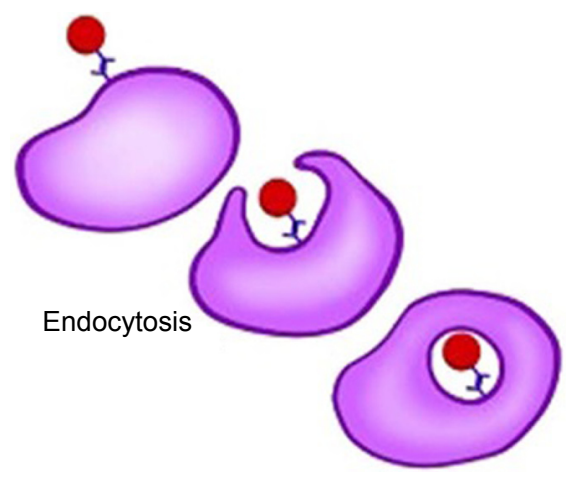

C

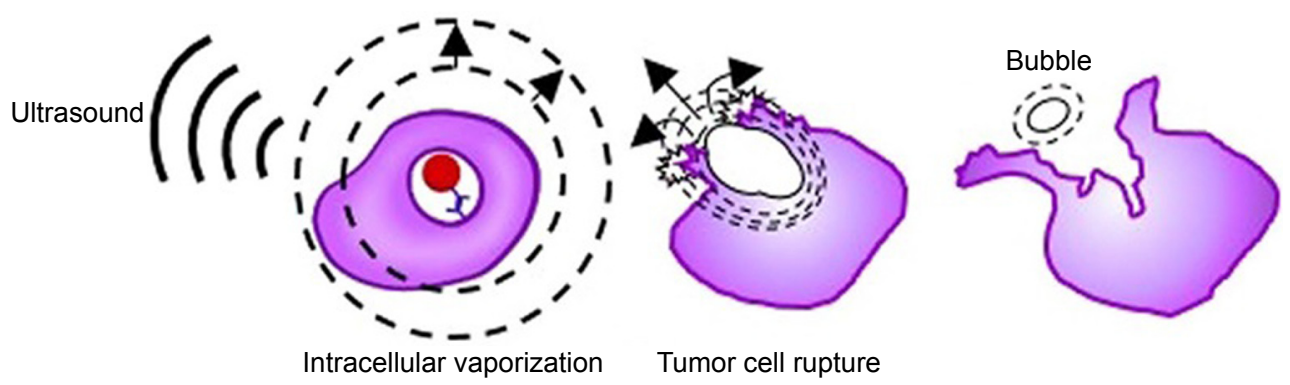

Figure 5 Schematic explaining the synergistic treatment of ultrasound with targeted liquid fluorocarbon droplets.

Notes: (A) The targeted liquid fluorocarbon droplets selectively adsorb to the cancer cell by the identification of the target. (B)Then the liquid fluorocarbon droplets enter the cancer cells via antibody-mediated endocytosis. (C) Then, vaporization by ultrasound exposure occurs in the tumor cell, resulting in a bigger bubble which induces the death of the tumor cell. Reproduced from Ishijima A, Minamihata K, Yamaguchi S, et al. Selective intracellular vaporisation of antibody-conjugated phase-change nano-droplets in vitro. Sci Rep. 2017;7:44077. Copyright @ 2017, Springer Nature. ${ }^{64}$

Most importantly, adoptive cell transfer provides a beneficial microenvironment to support antitumor immunity. Until now, the most widely used immune cells in ACT have been NK cells. Transferred adoptive cells can proliferate in the new host and retain their antitumor ability. First, reinjection of a large amount of adoptive cells leads to unpredictable side effects, such as pyrexia and anaphylaxis. ${ }^{75}$ Second, the number of adoptive cells delivered to the targeted areas is always too low to play an effective role in killing tumor cells. Furthermore, the normal functions of adoptive cells may be influenced by the ex vivo expansion strategy as well as the immunosuppressive effect of the self-tumor microenvironment. $^{76}$

\section{NK-cell-based immunotherapy}

NK cells are a type of cytotoxic T-lymphocyte that play an important antitumor role in the innate immune system. In addition, NK cells can regulate immune function as well as kill tumor cells. ${ }^{77}$ Furthermore, NK cells can induce tumor cell apoptosis in an antigen-dependent method when the antibody is adherent to the receptors. NK-92 is a human NK cell line, which has been demonstrated to have connection with tumor-associated antigens in tumor tissues. However, in clinical trials, the effectiveness of NK cells in treating cerebral tumors is restricted by their poor ability to traverse the BBB. ${ }^{78}$ The BBB limits the passage of most substances, including cells, nucleic acids and antibodies, from the blood circulation into the brain tissue, thus suppressing their treatment effect.

Fortunately, recent studies have shown the potential to transiently open the BBB, enabling enhanced permeation of drugs or genes. O'Reilly et al investigated the time taken for the BBB to close and the opening volume on the time scale of closure after focused US exposure; no significant differences were detected on MRI between large- and smallvolume sonications, suggesting that safe BBB opening can be achieved by US combined with microbubbles. ${ }^{79}$ Lin et al demonstrated that the BBB can be successfully opened by US-triggered microbubble destruction and thus the delivery of exogenous substances can be significantly improved, although the specific mechanisms are still unclear. ${ }^{80}$ So far, the following statements can be made: the ARF pushes microbubbles toward the vascular wall and promotes an impact on vascular cells that induces a loose intercellular gap; and microbubbles inside the vasculature can produce microstreams and shock waves, thus compromising the stability of the vascular wall. After the safe BBB disruption with focused ultrasound (FUS) and microbubbles (Figure 6), NK-92 cells are largely delivered into brain tumor tissues and exert their anticancer effects, causing a higher suppression of tumor growth and longer survival time in a mouse brain tumor model compared to the non-treatment prototype. ${ }^{81}$ 


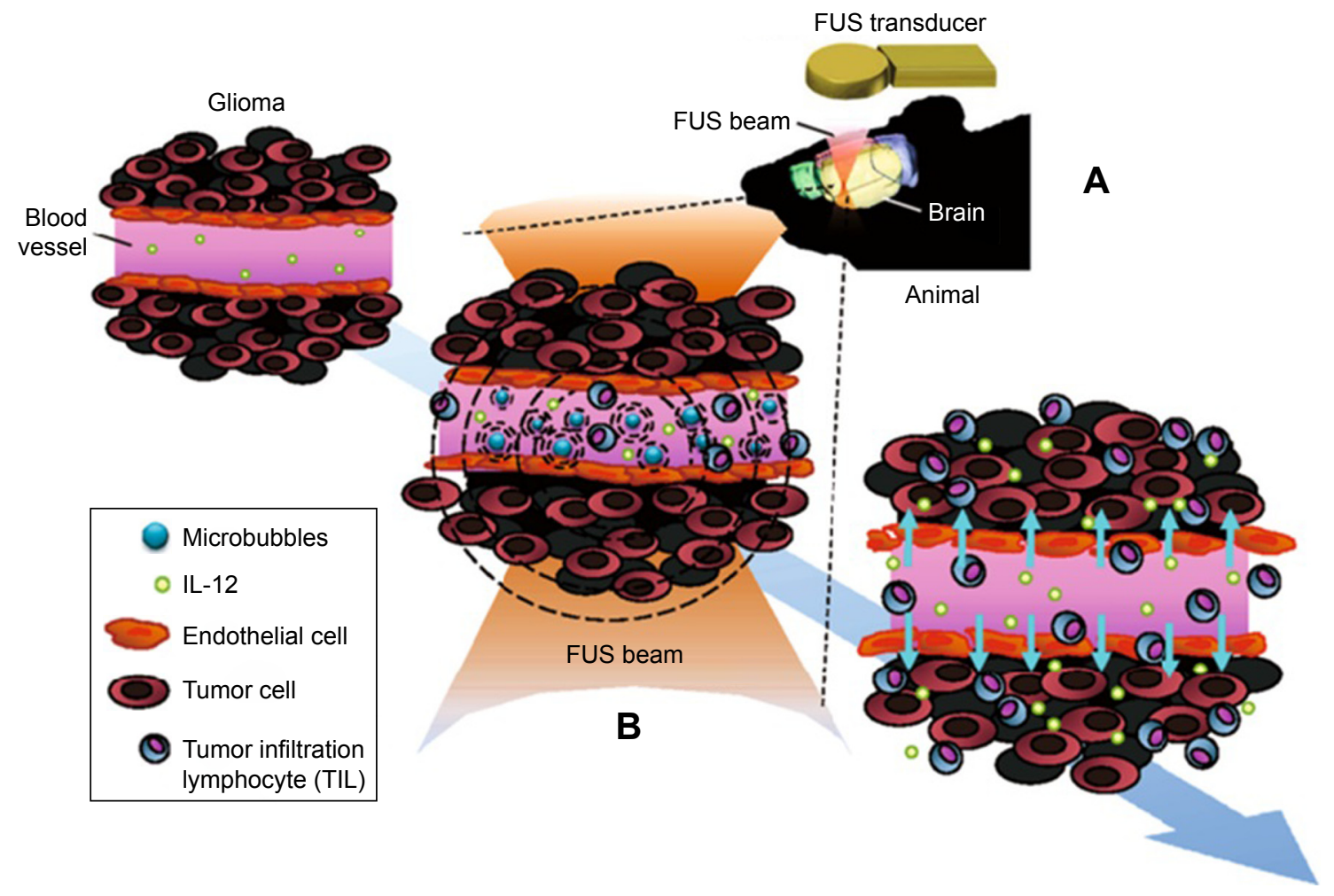

Figure 6 Schematic of FUS-induced BBB opening to enhance IL- 12 delivery in brain glioma treatment.

Notes: (A) The FUS transducer produces an FUS beam to the brain. (B) The microbubbles in the capillaries of brain tissue oscillate and explode under the FUS, and thus induce BBB opening. Therapeutic molecules such as IL-12 can then be delivered into the brain tumor effectively to trigger local immunological effects to improve the antitumor effect. Reproduced from Alkins R, Burgess A, Kerbel R, Wels WS, Hynynen K, Francia G. Early treatment of HER2-amplified brain tumors with targeted NK-92 cells and focused ultrasound improves survival. Neuro Oncol. 2016;18(7):974-981. ${ }^{81}$

Abbreviations: BBB, blood-brain barrier; FUS, focused ultrasound; IL-I2, interleukin- 12.

Alkins et al labeled HER2 high-expressing breast tumor cells with superparamagnetic iron oxide (SPIO) and implanted them into nude rats. Following transcranial FUS irradiation and intravenous injection of SPIO-labeled NK cells, MRI showed a remarkable spark drop, indicating successful homing clustering of NK cells. ${ }^{82}$

\section{T-cell-based immunotherapy}

Tregs are known to produce ILs and transforming growth factors, but they have an inhibitory effect on tumor-associated APCs because tumor-associated APCs, such as DCs, lose their co-stimulatory ligands, causing an inability to support T-cell activation. ${ }^{83}$ In addition, $\mathrm{CD} 4{ }^{+} \mathrm{CD} 25^{+}$Tregs are reported to have an important effect on antitumor immune responses. ${ }^{84}$ Tregs may induce immune tolerance to self-antigens and suppress the self-immune response against cancer by suppressing reactive immune cells. In addition, the poor clinical efficacy of antitumor immunotherapy may result from the excessive presence of Tregs. ${ }^{85,86}$ Therefore, the strategy of using targeted Tregs will be an effective treatment to enhance antitumor immunotherapy.$^{87}$ Shi et al studied the treatment effects on the viability of $\mathrm{CD} 4^{+} \mathrm{CD} 25^{+}$Tregs induced by the combination of US and SonoVue ${ }^{\circledR}$ (Bracco Co. Geneva, Switzerland) microbubbles, and explored the optimal US parameters for Treg transfection. Their results suggest that US and microbubbles have a synergistic effect on the enhancement of Treg proliferation, and the optimal Treg transfer rate was acquired by irradiation with US for 150/180 seconds under a US mechanical index of 1.4 in the presence of $10 \%$ microbubbles.$^{88-90}$

\section{Cytokine immunotherapy}

The aim of cytokine immunotherapy is to deliver cytokines to a local area at a high concentration to induce a forceful antitumor immune response. In the recent literature on cytokine immunotherapy triggered by US and microbubbles, several trials have delivered cytokines, including IL-2, IL-10 and IL-13, as well as tumor growth factors, to stimulate an immune response. ${ }^{72,91}$

\section{IL-based immunotherapy}

ILs have been reported to have an antitumor effect because they can serve as immunostimulatory molecules that can trigger an antitumor immune response. Among the cytokines mentioned in the previous paragraph, IL-12 plays the most important role in immunity and tumor angiogenesis; thus, it has garnered the most attention. IL-12 is a heterodimeric 
protein consisting of $\mathrm{p} 35$ and $\mathrm{p} 40$ subunits produced by DCs and macrophages, and has multiple immunoregulatory and antitumor effects. ${ }^{92}$

In turn, activated T cells increase the level of IFN- $\gamma$, which triggers positive feedback on APCs to secrete IL-12. ${ }^{93}$ Suzuki et al assessed the utility of the combination of IL-12-loaded microbubbles and US in cancer therapy and found that this system can induce a T-cell-dependent immune response that can dramatically suppress tumor growth. ${ }^{94}$ In addition, Chen et al applied FUS to induce BBB opening and subsequent safe IL-12 delivery, and found that this method activated local immune responses to enhance antitumor effects. ${ }^{95}$

\section{IFN-based immunotherapy}

IFN has several biological effects, such as immunoregulation and anti-proliferative activities, on some cancer cells. Moreover, IFN induces cell apoptosis, resulting in tumor inhibition. Sakakima et al examined tumor suppression after IFN gene transfection with the combination of US and a mixture of IFN and microbubbles. The results revealed that the tumor size was significantly reduced after IFN gene transfection, indicating that IFN-based antitumor immunotherapy with sonoporation may be a new treatment option for tumors. ${ }^{96,97}$

\section{Conclusions and future prospects}

UMMD is now considered to be a promising non-viral gene/ drug delivery system. This technology combines the advantages of microbubbles/nanodroplets and US in such a way that US-triggered microbubbles or nanodroplet destruction induces a series of physical effects. Thus, the permeability of physiological barriers can be instantaneously enhanced, allowing immunostimulatory materials (ie, antibodies, antigens, immune cells and vaccines) to traverse across the barriers to exert their effects. ${ }^{98}$ Antitumor immune responses have been achieved by delivering immunostimulatory substances using the combination of US and microbubbles and nanoparticles. UMMD-mediated immunotherapy is in its infancy, but provides promising strategies for cancer treatment.

Recent research progress concerning the dynamic and complicated interactions between the immune system and cancer plays a role in guiding cancer immunotherapy, which will be available for innovative cancer therapy. Numerous studies have utilized microbubbles/nanoparticles as delivery vehicles in combination with US to transport antibodies, antigens and immunostimulatory molecules to APCs, which have shown enhanced $\mathrm{CD}^{+}$and $\mathrm{CD}^{+} \mathrm{T}$ responses against tumors. Likewise, other macromolecules, including miRNA and pDNA, can be delivered into tumor tissues in this way.
However, both microbubbles and nanoparticles have two major disadvantages for utilization as delivery carriers to tumor cells. First, they are too large to easily and effectively traverse many barriers. Second, the half-life of gas-filled microbubbles or nanobubbles is fairly short in vivo, resulting in a poor US-triggered ability. Furthermore, the low systemic cytotoxicity, high specificity and lasting efficacy, as well as the good bioavailability of gene/ drug vehicles, are clinically challenging for optimizing delivery technology. ${ }^{99}$

The improvement of this method relies on several main strategies. The first possible solution to this issue is replacing the gas in the microbubble with perfluorooctylbromide. Although some researchers have explored this idea and generated results, further study is required. ${ }^{100}$ Another potential method is using targeting ligands specific to immune cells, ${ }^{101}$ so that effective immunotherapy can be optimized. Finally, when using UMMD-based immunotherapies, the differences between liquid and solid tumors should be considered.

\section{Acknowledgments}

This work is supported by the Research Projects of the National Natural Science Foundation of China (number 81671707), the Natural Science Foundation of Guangdong Province (number 2016A030311054), the Research Projects of Guangzhou Technology Bureau (number 201607010201) and the Research Fund for Lin He's Academician Workstation of New Medicine and Clinical Translation.

\section{Disclosure}

The authors report no conflicts of interest in this work.

\section{References}

1. Torre LA, Bray F, Siegel RL, Ferlay J, Lortet-Tieulent J, Jemal A. Global cancer statistics, 2012. CA Cancer J Clin. 2015;65(2):87-108.

2. Lindau D, Gielen P, Kroesen M, Wesseling P, Adema GJ. The immunosuppressive tumour network: myeloid-derived suppressor cells, regulatory T cells and natural killer T cells. Immunology. 2013;138(2): 105-115.

3. Miller JFAP, Sadelain M. The journey from discoveries in fundamental immunology to cancer immunotherapy. Cancer Cell. 2015;27(4): 439-449.

4. Knutson KL, Karyampudi L, Lamichhane P, Preston C. Targeted immune therapy of ovarian cancer. Cancer Metastasis Rev. 2015;34(1): 53-74.

5. Topalian SL, Drake CG, Pardoll DM. Immune checkpoint blockade: a common denominator approach to cancer therapy. Cancer Cell. 2015; 27(4):450-461.

6. Wang W, Xia X, Wu S, et al. Cancer immunotherapy: A need for peripheral immunodynamic monitoring. Am J Reprod Immunol. 2017; 20(Pt 1):e12793.

7. Madorsky Rowdo FP, Baron A, Urrutia M, Mordoh J. Immunotherapy in Cancer: A Combat between Tumors and the Immune System; You Win Some, You Lose Some. Front Immunol. 2015;6(23):127. 
8. Kapadia CH, Perry JL, Tian S, Luft JC, DeSimone JM. Nanoparticulate immunotherapy for cancer. J Control Release. 2015;219:167-180.

9. Yadav M, Delamarre L. IMMUNOTHERAPY. Outsourcing the immune response to cancer. Science. 2016;352(6291):1275-1276.

10. Rosenberg SA. Decade in review-cancer immunotherapy: entering the mainstream of cancer treatment. Nat Rev Clin Oncol. 2014;11(11):630-632.

11. Yu B, Wang J, He C, et al. Cytokine-induced killer cell therapy for modulating regulatory $\mathrm{T}$ cells in patients with non-small cell lung cancer. Exp Ther Med. 2017;14(1):831-840.

12. Fontana F, Liu D, Hirvonen J, Santos HA. Delivery of therapeutics with nanoparticles: what's new in cancer immunotherapy? Wiley Interdiscip Rev Nanomed Nanobiotechnol. 2017;9(1):e1421.

13. Chen Z-Y, Liang K, Qiu R-X. Targeted gene delivery in tumor xenografts by the combination of ultrasound-targeted microbubble destruction and polyethylenimine to inhibit survivin gene expression and induce apoptosis. J Exp Clin Cancer Res. 2010;29(1):152.

14. Aryal M, Park J, Vykhodtseva N, Zhang Y-Z, McDannold N. Enhancement in blood-tumor barrier permeability and delivery of liposomal doxorubicin using focused ultrasound and microbubbles: evaluation during tumor progression in a rat glioma model. Phys Med Biol. 2015; 60(6):2511-2527.

15. Chen Z-Y, Yang F, Lin Y, et al. New development and application of ultrasound targeted microbubble destruction in gene therapy and drug delivery. Curr Gene Ther. 2013;13(4):250-274.

16. Luo MH, Yeh CK, Situ B, Yu JS, Li BC, Chen ZY. Microbubbles: A Novel Strategy for Chemotherapy. Curr Pharm Des. 2017;23(23) 3383-3390.

17. Kang ST, Yeh CK. Ultrasound microbubble contrast agents for diagnostic and therapeutic applications: current status and future design. Chang Gung Med J. 2012;35(2):125-139.

18. Carson AR, Mctiernan CF, Lavery L, et al. Ultrasound-targeted microbubble destruction to deliver siRNA cancer therapy. Cancer Res. 2012;72(23):6191-6199.

19. Fan $\mathrm{CH}$, Lin CY, Liu HL, Yeh CK. Ultrasound targeted CNS gene delivery for Parkinson's disease treatment. J Control Release. 2017;261: 246-262.

20. Vanbavel E. Effects of shear stress on endothelial cells: Possible relevance for ultrasound applications. Prog Biophys Mol Biol. 2007; 93(1-3):374-383.

21. Wu J, Nyborg WL. Ultrasound, cavitation bubbles and their interaction with cells. Adv Drug Deliv Rev. 2008;60(10):1103-1116.

22. Mauri G, Nicosia L, Xu Z, et al. Focused ultrasound: tumor ablation and its potential to enhance immunological therapy to cancer. $\mathrm{Br} J$ Radiol. 2018;91(1083):20170641.

23. Jin Q, Kang S-T, Chang Y-C, Zheng H, Yeh C-K. Inertial cavitation initiated by polytetrafluoroethylene nanoparticles under pulsed ultrasound stimulation. Ultrason Sonochem. 2016;32:1-7.

24. Liu H-L, Fan C-H, Ting C-Y, Yeh C-K. Combining microbubbles and ultrasound for drug delivery to brain tumors: current progress and overview. Theranostics. 2014;4(4):432-444.

25. Qin P, Han T, Yu A, Xu L. Mechanistic understanding the bioeffects of ultrasound-driven microbubbles to enhance macromolecule delivery. J Control Release. 2018;272:169-181.

26. Andrews NW, Corrotte M, Castro-Gomes T. Above the fray: Surface remodeling by secreted lysosomal enzymes leads to endocytosismediated plasma membrane repair. Semin Cell Dev Biol. 2015;45: 10-17.

27. Fan P, Zhang Y, Guo X, et al. Cell-cycle-specific Cellular Responses to Sonoporation. Theranostics. 2017;7(19):4894-4908.

28. Fan Z, Kumon RE, Park J, Deng CX. Intracellular delivery and calcium transients generated in sonoporation facilitated by microbubbles. J Control Release. 2010;142(1):31-39.

29. Tam C, Idone V, Devlin C, et al. Exocytosis of acid sphingomyelinase by wounded cells promotes endocytosis and plasma membrane repair. J Cell Biol. 2010;189(6):1027-1038.

30. Kooiman K, Vos HJ, Versluis M, de Jong N. Acoustic behavior of microbubbles and implications for drug delivery. Adv Drug Deliv Rev. 2014;72(22):28-48.
31. Kuznetsova LA, Coakley WT. Applications of ultrasound streaming and radiation force in biosensors. Biosens Bioelectron. 2007;22(8): $1567-1577$.

32. Rychak JJ, Klibanov AL, Hossack JA. Acoustic radiation force enhances targeted delivery of ultrasound contrast microbubbles: in vitro verification. IEEE Trans Ultrason Ferroelectr Freq Control. 2005;52(3):421-433.

33. Herbst EB, Unnikrishnan S, Wang S, Klibanov AL, Hossack JA, Mauldin FW Jr. The Use of Acoustic Radiation Force DecorrelationWeighted Pulse Inversion for Enhanced Ultrasound Contrast Imaging. Invest Radiol. 2017;52(2):95-102.

34. Fang RH, Zhang L. Nanoparticle-Based Modulation of the Immune System. Annu Rev Chem Biomol Eng. 2016;7(1):305-326.

35. Kumari P, Ghosh B, Biswas S. Nanocarriers for cancer-targeted drug delivery. J Drug Target. 2016;24(3):179-191.

36. Frey AB. Suppression of T cell responses in the tumor microenvironment. Vaccine. 2015;33(51):7393-7400.

37. Koo H, Huh MS, Sun I-C, et al. In Vivo Targeted Delivery of Nanoparticles for Theranosis. Acc Chem Res. 2011;44(10):1018-1028.

38. Gradishar WJ, Tjulandin S, Davidson N, et al. Phase III trial of nanoparticle albumin-bound paclitaxel compared with polyethylated castor oil-based paclitaxel in women with breast cancer. J Clin Oncol. 2005; 23(31):7794-7803.

39. Paz-Ares L, Ross H, O'Brien M, et al. Phase III trial comparing paclitaxel poliglumex vs docetaxel in the second-line treatment of non-small-cell lung cancer. Br J Cancer. 2008;98(10):1608-1613.

40. Blum NT, Yildirim A, Chattaraj R, Goodwin AP. Nanoparticles Formed by Acoustic Destruction of Microbubbles and Their Utilization for Imaging and Effects on Therapy by High Intensity Focused Ultrasound. Theranostics. 2017;7(3):694-702.

41. Zhou Y, Wang Z, Chen Y, et al. Microbubbles from gas-generating perfluorohexane nanoemulsions for targeted temperature-sensitive ultrasonography and synergistic HIFU ablation of tumors. Adv Mater. 2013;25(30):4123-4130.

42. Sheeran PS, Dayton PA. Phase-change contrast agents for imaging and therapy. Curr Pharm Des. 2012;18(15):2152-2165.

43. Ho YJ, Chang YC, Yeh CK. Improving Nanoparticle Penetration in Tumors by Vascular Disruption with Acoustic Droplet Vaporization. Theranostics. 2016;6(3):392-403.

44. Zhou Y. Application of acoustic droplet vaporization in ultrasound therapy. J Ther Ultrasound. 2015;3(1):20.

45. Yang Q, Nanayakkara GK, Drummer C, et al. Low-Intensity UltrasoundInduced Anti-inflammatory Effects Are Mediated by Several New Mechanisms Including Gene Induction, Immunosuppressor Cell Promotion, and Enhancement of Exosome Biogenesis and Docking. Front Physiol. 2017;8:818.

46. Zhang W, Shou W-D, Xu Y-J, Bai W-K, Hu B. Low-frequency ultrasound-induced VEGF suppression and synergy with dendritic cell-mediated anti-tumor immunity in murine prostate cancer cells in vitro. Sci Rep. 2017;7(1):5778.

47. Moyer TJ, Zmolek AC, Irvine DJ. Beyond antigens and adjuvants: formulating future vaccines. J Clin Invest. 2016;126(3):799-808.

48. Schreibelt G, Bol KF, Westdorp H, et al. Effective Clinical Responses in Metastatic Melanoma Patients after Vaccination with Primary Myeloid Dendritic Cells. Clin Cancer Res. 2016;22(9):2155-2166.

49. Tjoa BA, Lodge PA, Salgaller ML, Boynton AL, Murphy GP. Dendritic cell-based immunotherapy for prostate cancer. CA Cancer J Clin. 1999;49(2):117-128.

50. Dewitte H, Van Lint S, Heirman C, et al. The potential of antigen and TriMix sonoporation using mRNA-loaded microbubbles for ultrasoundtriggered cancer immunotherapy. J Control Release. 2014;194(12): $28-36$.

51. Oda Y, Suzuki R, Otake S, et al. Prophylactic immunization with Bubble liposomes and ultrasound-treated dendritic cells provided a four-fold decrease in the frequency of melanoma lung metastasis. $J$ Control Release. 2012;160(2):362-366.

52. Kutzler MA, Weiner DB. DNA vaccines: ready for prime time? Nat Rev Genet. 2008;9(10):776-788. 
53. Stifter K, Schuster C, Schlosser M, Boehm BO, Schirmbeck R. Exploring the induction of preproinsulin-specific Foxp3+CD4+ Treg cells that inhibit CD $8+\mathrm{T}$ cell-mediated autoimmune diabetes by DNA vaccination. Sci Rep. 2016;6:29419.

54. Gong Y-F, Zhou Q-B, Liao Y-D, et al. Optimized construction of MUC1-VNTRn DNA vaccine and its anti-pancreatic cancer efficacy. Oncol Lett. 2017;13(4):2198-2206.

55. Melief CJM. Cancer Immunotherapy by Dendritic Cells. Immunity. 2008;29(3):372-383.

56. Suzuki R, Oda Y, Utoguchi N, et al. A novel strategy utilizing ultrasound for antigen delivery in dendritic cell-based cancer immunotherapy. J Control Release. 2009;133(3):198-205.

57. Un K, Kawakami S, Suzuki R, Maruyama K, Yamashita F, Hashida M. Suppression of melanoma growth and metastasis by DNA vaccination using an ultrasound-responsive and mannose-modified gene carrier. Mol Pharm. 2011;8(2):543-554.

58. Un K, Kawakami S, Suzuki R, Maruyama K, Yamashita F, Hashida M. Development of an ultrasound-responsive and mannose-modified gene carrier for DNA vaccine therapy. Biomaterials. 2010;31(30): 7813-7826.

59. Yoshida M, Kawakami S, Kono Y, et al. Enhancement of the anti-tumor effect of DNA vaccination using an ultrasound-responsive mannosemodified gene carrier in combination with doxorubicin-encapsulated PEGylated liposomes. Int J Pharm. 2014;475(1-2):401-407.

60. Weiner LM, Murray JC, Shuptrine CW. Antibody-based immunotherapy of cancer. Cell. 2012;148(6):1081-1084.

61. Sandler A, Gray R, Perry MC, et al. Paclitaxel-carboplatin alone or with bevacizumab for non-small-cell lung cancer. N Engl J Med. 2006; 355(24):2542-2550.

62. Liu H-L, Hsu P-H, Lin C-Y, et al. Focused Ultrasound Enhances Central Nervous System Delivery of Bevacizumab for Malignant Glioma Treatment. Radiology. 2016;281(1):99-108.

63. Marcus R, Imrie K, Belch A, et al. CVP chemotherapy plus rituximab compared with CVP as first-line treatment for advanced follicular lymphoma. Blood. 2005;105(4):1417-1423.

64. Ishijima A, Minamihata K, Yamaguchi S, et al. Selective intracellular vaporisation of antibody-conjugated phase-change nano-droplets in vitro. Sci Rep. 2017;7:44077.

65. Zhou S, Zhang X, Wang C. Rituximab-conjugated, doxorubicinloaded microbubbles as a theranostic modality in B-cell lymphoma. Oncotarget. 2016;8(3):4760-4772.

66. Minchinton AI, Tannock IF. Drug penetration in solid tumours. Nat Rev Cancer. 2006;6(8):583-592.

67. Nuti M, Bellati F, Visconti V, et al. Immune Effects of Trastuzumab. J Cancer. 2011;2(1):317-323.

68. Horton JK, Halle J, Ferraro M, et al. Radiosensitization of chemotherapy-refractory, locally advanced or locally recurrent breast cancer with trastuzumab: a phase II trial. Int J Radiat Oncol Biol Phys. 2010; 76(4):998-1004.

69. Chen P-Y, Wei K-C, Liu H-L. Neural immune modulation and immunotherapy assisted by focused ultrasound induced blood-brain barrier opening. Hum Vaccin Immunother. 2015;11(11):2682-2687.

70. Centelles MN, Wright M, Gedroyc W, Thanou M. Focused ultrasound induced hyperthermia accelerates and increases the uptake of anti-HER-2 antibodies in a xenograft model. Pharmacol Res. 2016;114:144-151.

71. Kobus T, Zervantonakis IK, Zhang Y, McDannold NJ. Growth inhibition in a brain metastasis model by antibody delivery using focused ultrasound-mediated blood-brain barrier disruption. J Control Release. 2016;238:281-288.

72. Andersen R, Donia M, Borch T, et al. Adoptive cell therapy with tumor infiltrating lymphocytes and intermediate dose IL-2 for metastatic melanoma. J Immunother Cancer. 2014;2(Suppl 3):P1.

73. Palucka K, Ueno H, Banchereau J. Recent developments in cancer vaccines. J Immunol. 2011;186(3):1325-1331.

74. Smith DM, Simon JK, Baker JR Jr. Applications of nanotechnology for immunology. Nat Rev Immunol. 2013;13(8):592-605.
75. Budhu S, Wolchok J, Merghoub T. The importance of animal models in tumor immunity and immunotherapy. Curr Opin Genet Dev. 2014; 24(4):46-51.

76. Singer BD, King LS, D’Alessio FR. Regulatory T cells as immunotherapy. Front Immunol. 2014;5:46.

77. Cheng M, Chen Y, Xiao W, Sun R, Tian Z. NK cell-based immunotherapy for malignant diseases. Cell Mol Immunol. 2013;10(3):230-252.

78. Sta Maria NS, Barnes SR, Weist MR, Colcher D, Raubitschek AA, Jacobs RE. Low Dose Focused Ultrasound Induces Enhanced Tumor Accumulation of Natural Killer Cells. PLoS One. 2015;10(11): e0142767.

79. O'Reilly MA, Hough O, Hynynen K. Blood-Brain Barrier Closure Time After Controlled Ultrasound-Induced Opening Is Independent of Opening Volume. J Ultrasound Med. 2017;36(3):475-483.

80. Lin C-Y, Hsieh H-Y, Pitt WG, et al. Focused ultrasound-induced blood-brain barrier opening for non-viral, non-invasive, and targeted gene delivery. J Control Release. 2015;212:1-9.

81. Alkins R, Burgess A, Kerbel R, Wels WS, Hynynen K, Francia G. Early treatment of HER2-amplified brain tumors with targeted NK-92 cells and focused ultrasound improves survival. Neuro Oncol. 2016; 18(7):974-981.

82. Alkins R, Burgess A, Ganguly M, et al. Focused ultrasound delivers targeted immune cells to metastatic brain tumors. Cancer Res. 2013; 73(6): 1892-1899.

83. Munn DH, Bronte V. Immune suppressive mechanisms in the tumor microenvironment. Curr Opin Immunol. 2016;39:1-6.

84. Read S, Malmström V, Powrie F. Cytotoxic T lymphocyte-associated antigen 4 plays an essential role in the function of $\mathrm{CD} 25^{+} \mathrm{CD} 4^{+}$regulatory cells that control intestinal inflammation. J Exp Med. 2000;192(2): 295-302.

85. Matheu MP, Othy S, Greenberg ML, et al. Imaging regulatory $\mathrm{T}$ cell dynamics and CTLA4-mediated suppression of T cell priming. Nat Commun. 2015;6(1):6219.

86. Shu Z, Shen Y, Song Y, Ying Y. How to detour Treg cells in T cell-based antitumor immune therapy. Onco Targets Ther. 2013;6:1243-1247.

87. Schabowsky RH, Madireddi S, Sharma R, Yolcu ES, Shirwan H. Targeting $\mathrm{CD} 4+\mathrm{CD} 25+\mathrm{FoxP} 3+$ regulatory T-cells for the augmentation of cancer immunotherapy. Curr Opin Investig Drugs. 2007;8(12): 1002-1008.

88. Shi C, Zhang Y, Yang H, et al. Combined effect of ultrasound/SonoVue microbubble on $\mathrm{CD} 4+\mathrm{CD} 25+$ regulatory $\mathrm{T}$ cells viability and optimized parameters for its transfection. Ultrasonics. 2015;62:97-102.

89. Zhou Q, Zhang Y, Du J, et al. Different-Sized Gold Nanoparticle Activator/Antigen Increases Dendritic Cells Accumulation in LiverDraining Lymph Nodes and CD8+ T Cell Responses. ACS Nano. 2016;10(2):2678-2692.

90. Rosalia RA, Cruz LJ, van Duikeren S, et al. CD40-targeted dendritic cell delivery of PLGA-nanoparticle vaccines induce potent anti-tumor responses. Biomaterials. 2015;40:88-97.

91. Mittal SK, Roche PA. Suppression of antigen presentation by IL-10. Curr Opin Immunol. 2015;34:22-27.

92. Alatrash G, Hutson TE, Molto L, et al. Clinical and immunologic effects of subcutaneously administered interleukin-12 and interferon alfa-2b: phase I trial of patients with metastatic renal cell carcinoma or malignant melanoma. J Clini Oncol. 2004;22(14):2891-2900.

93. Cicchelero L, Denies S, Haers H, et al. Intratumoural interleukin 12 gene therapy stimulates the immune system and decreases angiogenesis in dogs with spontaneous cancer. Vet Comp Oncol. 2016;15(4): $1187-1205$.

94. Suzuki R, Namai E, Oda Y, et al. Cancer gene therapy by IL-12 gene delivery using liposomal bubbles and tumoral ultrasound exposure. J Control Release. 2009;35(8):245-250.

95. Chen P-Y, Hsieh H-Y, Huang C-Y, et al. Focused ultrasound-induced blood-brain barrier opening to enhance interleukin-12 delivery for brain tumor immunotherapy: a preclinical feasibility study. J Transl Med. 2015;13(1):93. 
96. Sakakima Y, Hayashi S, Yagi Y, Hayakawa A, Tachibana K, Nakao A. Gene therapy for hepatocellular carcinoma using sonoporation enhanced by contrast agents. Cancer Gene Ther. 2005;12(11):884-889.

97. Liu S-Y, Wei W, Yue H, et al. Nanoparticles-based multi-adjuvant whole cell tumor vaccine for cancer immunotherapy. Biomaterials. 2013;34(33):8291-8300.

98. Escoffre JM, Deckers R, Bos C, Moonen C. Bubble-Assisted Ultrasound: Application in Immunotherapy and Vaccination. Adv Exp Med Biol. 2016;880:243-261.
99. Zang X, Zhao X, Hu H, Qiao M, Deng Y, Chen D. Nanoparticles for tumor immunotherapy. Eur J Pharm Biopharm. 2017;115:243-256.

100. Singh R, Husseini GA, Pitt WG. Phase transitions of nanoemulsions using ultrasound: experimental observations. Ultrason Sonochem. 2012;19(5):1120-1125.

101. Zhu L, Zhao H, Zhou Z, et al. Peptide-Functionalized Phase-Transformation Nanoparticles for Low Intensity Focused Ultrasound-Assisted Tumor Imaging and Therapy. Nano Lett. 2018;18(3):1831-1841.

\section{Publish your work in this journal}

OncoTargets and Therapy is an international, peer-reviewed, open access journal focusing on the pathological basis of all cancers, potential targets for therapy and treatment protocols employed to improve the management of cancer patients. The journal also focuses on the impact of management programs and new therapeutic agents and protocols on

\section{Dovepress}

patient perspectives such as quality of life, adherence and satisfaction. The manuscript management system is completely online and includes a very quick and fair peer-review system, which is all easy to use. Visit http://www.dovepress.com/testimonials.php to read real quotes from published authors.

Submit your manuscript here: http://www.dovepress.com/oncotargets-and-therapy-journal 